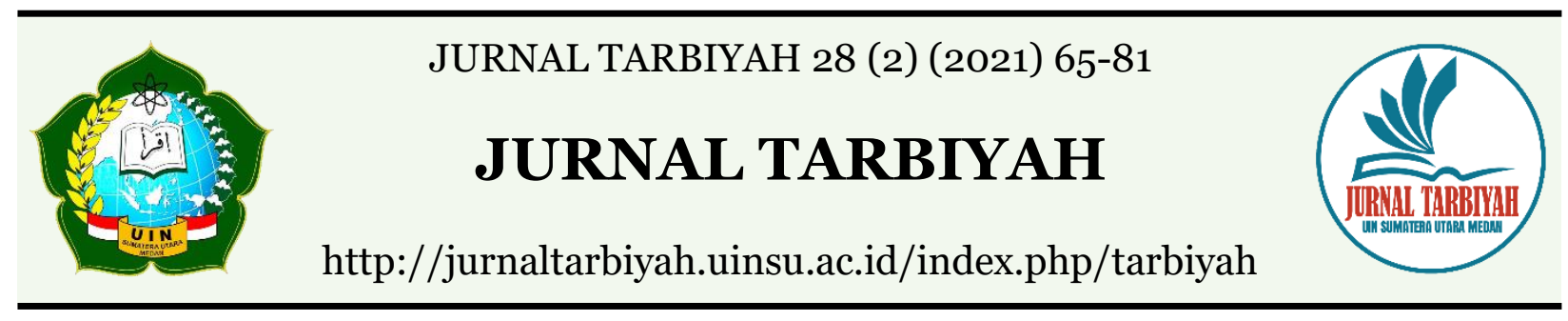

\title{
THE DEVELOPMENT OF AUDIOVISUAL TEACHING MEDIA BASED ON GRAPHIC ORGANIZER TO IMPROVE STUDENTS' ABILITY IN FINDING THE MAIN IDEA OF A PARAGRAPH
}

\author{
Euis Indah Kesuma Ningsih', Auffah Yumni², Riris Nurkholidah Rambe3 \\ ${ }^{1}$ Sekolah Dasar Negeri 17 Tanjung Selamat \\ 2,3 Universitas Islam Negeri Sumatera Utara Medan \\ Email: ${ }^{1}$ euisindahog@gmail.com, ${ }^{2}$ auffahyumni@uinsu.ac.id, \\ 3 ririsnurkholida@uinsu.ac.id
}

DOI : 10.30829/tar.v28i2.1118

Accepted: October 9th, 2021. Approved: December 28th, 2021. Published: December 30th, 2021

\begin{abstract}
This study aims to determine the validity, practicality, and effectiveness of the development of audio-visual teaching media based on Graphic Organizer to improve students' ability to find the main idea of a paragraph at the fifth grade of MIN 2 in Labuhanbatu Selatan. This study follows the Research and Development (R \& D) developed by Borg and Gall and has been modified by Sugiyono. This includes nine steps, namely; Potential and Problems, Gathering Information, Product Design, Design Validation, Design Revision, Product Trial, Revision Product, Trial of Use, and Revision of Final Products. The data were collected from interviews, observation, and questionnaires. There were three instruments used, namely preliminary instruments, product development instruments, and product testing instruments. The data were analyzed using descriptive qualitative and quantitative analysis to describe the results of product development. The findings of this study indicate that 1) the validity of assessment made by the material experts of the product media was found to be $80 \%$. The media expert's assessment of product media obtained a percentage of $86.6 \%$; 2) In terms of the practicality of the product, the percentage of responses given by small-scale students shows $97.6 \%$ and the percentage of responses given by large-scale students is $98.4 \%$. Meanwhile, the results of the questionnaires filled by the teacher is $100 \%$, which is adjusted to the practicality criteria table; 3 ) the average score for the effectiveness before using the product is $76.87 \%$. Meanwhile, the average score for the effects after using the product is 94.37
\end{abstract}

Keywords: Audio Visual Teaching Media Based on Graphic Organizer, Main Idea of a Paragraph 


\section{INTRODUCTION}

Indonesian is a subject taught in elementary schools from the first grade to the sixth grade. Indonesian subject consists of many materials to be taught, one of which is to find the main idea of a paragraph. Finding the main idea of a paragraph is closely related to reading. In reading activities, students are required to read a text, and then they are asked to find the idea from the text. In this study, reading is an activity to find the main idea in each paragraph, to understand the main idea and the supporting details of a paragraph (Gurusinga , 2016).

The media chosen for teaching must be effective for helping the students in understanding a subject because the effectiveness of good teaching media will depend on the learning activities. Damanik, Sagala and Rezeki (2021) suggest that to deliver a successful learning objective, the teacher plans the lesson based on situational decisions. One of them is in determining the selection of learning models that will be used when the students practice in the class.

However, when the researchers observed and interviewed the fifth-grade teacher at MIN 2 of Labuhanbatu Selatan, it was found that the media used by the teacher was categorized as conventional media, such as the lecturing method, and the students' performance has not reached the KKM score (the minimum standard score) which is 75 according to the Indonesian curriculum 13. Meanwhile, there are only 10 students in the fifth grade of MIN 2 in Labuhanbatu Selatan. The results of the achievement of the Indonesian language scores obtained by the fifth-grade students of MIN 2 Labuhanbatu Selatan can be seen in the following table (table 1.1) below.

Table 1 The average score of Indonesian subjects taught to the fifth-grade ofvMIN 2 Labuhanbatu Selatan T.A 2020/2021

\begin{tabular}{|c|c|c|}
\hline $\begin{array}{c}\text { Students Learning } \\
\text { Outcome }\end{array}$ & Number of students & Percentage \\
\hline Mastery & 10 & $31,2 \%$ \\
\hline Not mastery yet & 22 & $68.8 \%$ \\
\hline Total & 32 & $100 \%$ \\
\hline
\end{tabular}

From the table above, it can be seen that the learning achievement of the fifthgrade students of MIN 2 Labuhanbatu Selatan in learning Indonesian subjects has not yet been achieved successfully. One of the reasons for low learning outcomes is that the rare 
usage of the right teaching media so that the students are less active in the learning process. Previous related studies, such as the research conducted by Anggraini (2020) entitled "Pengembangan Bahan Ajar Membaca Sastra Berbasis Graphic Organizer Venn Diagram di Sekolah Dasar, Volume 4 No. 4" indicated that literary reading materials based on Graphic Organizer Venn Diagram were found to be valid, practical and efficient. Research conducted by Ani (2019) entitled "Penerapan Metode Graphic Organizer pada Pembelajaran Bahasa Indonesia Siswa Kelas V SD Negeri o6 Bathin Solapan, Volume 3 No. 3 " indicated that the application of Graphic Organizer as a learning method can improve learning outcomes of Indonesian subjects in the fifth-grade students of SD Negeri 06 Bathin Solapan.

Trisna (2017) conducted a study on "Pengaruh Metode Pembelajaran Guided Note Taking dengan Berbantuan Media Audio Visual terhadap Minat dan Hasil Belajar Siswa Kelas V pada Mata Pelajaran IPA di SD Markus Medan, ISBN: 978-602-509761-4" indicates that the application of the Guide Note Taking learning model supported by Audio Visual Media can affect interest and learning outcomes in science lessons at SD Markus Medan. Monitoring the existing relevant problems and research, the researcher decided to develop a product, namely teaching media in the form of audio-visual based Graphic Organizer to be applied in the subject matter of the main idea of the paragraph so that the students can understand the problems of learning material to achieve success and completeness during the teaching and learning process. In addition, it helps the teacher focus on the level of learning outcomes and activities in the classroom. The audiovisual developed by the researcher as a product is in the form of videos using four types of Graphic Organizers, namely; Main Idea Chart, Spider Web Diagram, Tree Diagram, Pyramid Table. The video contains a story text with explanations on how to work on the worksheets. Based on the above background information, the researchers are motivated to conduct a development-based research entitled "Pengembangan Media Ajar Audio Visual Berbasis Graphic Organizer untuk Meningkatkan Kemampuan Siswa dalam Menentukan Ide Pokok Paragraf di Kelas V MIN 2 Labuhanbatu Selatan, T.A. 2020 2021."

\section{LITERATURE REVIEWS}

The learning process is also a communication process, so the media used in learning is called learning media. According to Hammid et al (2010), learning media are tools used to convey the content of teaching materials and can encourage students to take 
part in the learning process. Learning media are everything (humans, objects, or the surrounding environment) that can be used to convey or distribute messages in learning so that it can stimulate the attention, interest, thoughts, and feelings of students in learning activities to achieve goals. Based on these explanations, it can be concluded that learning media is something that can be used in delivering lessons to students by utilizing everything that exists that can stimulate students to pay attention, and have interest in learning.

Ummysalam (2017) stated that audio-visual media are intermediary media or material media which is absorbed from sight and hearing to build conditions that can enable students to acquire knowledge, skills, or attitudes. According to Purwono et al (2014), audio-visual media is a combination of audio and visual media in audio cassettes that have elements of sound and images that are commonly seen, for example, video recordings, sound slides, and so on. Looking at the opinions of several experts, it can be summarized that audio-visual media is a combination of media and audio where its application is through senses of hearing and sight in students, which uses tools such as television, films, and so on related to hearing and vision. Muhammad (2010) in an Islamic perspective, regarding audio-visual media, refers to Q.S. Al-Mu'miun verse 78 that states:

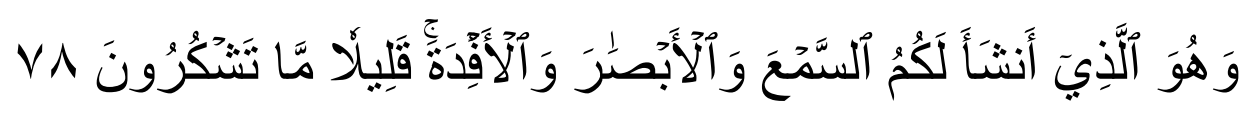

(23:78) And it is He who produced for you hearing and vision and hearts; little are you grateful. (Shahih International)

The verse above shows that audio-visual media (hearing/sight) has an important role for humans to know something or to learn science. We should be grateful for what is given so that we can see and hear both in daily life and most importantly in learning.

According to Mulyani (2014), a Graphic Organizer is a tool for teacher and students in learning. This tool functions to assist teacher in providing understanding to students and at the same time, it helps students to understand learning material. Because Graphic Organizer presents material through visual and spatial modalities (and reinforces what is taught in the classroom), the use of Graphic Organizer helps students internalize what they learn (Sudarmawan, 2014). Kurniawan (2018) says that graphic organizers are visual symbols that become communication tools that express ideas and concepts in stating their meaning. Graphic Organizer is a model that turns ideas and concepts into visual 
forms. Graphic Organizers are made of lines, arrows, and circles that show the relationships between main ideas. Candler (2012) states in his book that Graphic Organizer comes in many shapes and sizes, but regardless of what they look like, Graphic Organizer serves the same general purpose. Graphic Organizer helps us organize and conceptualize information so that we can better understand it. From the explanation above, it can be concluded that the Graphic Organizer is a learning model that can be used during the teaching and learning process. Line, circle, arrow, or picture functions to display the visual forms of ideas that students have. It is important to organize various knowledge that students can easily understand.

Graphic Organizers can help develop knowledge about cause and effect, compare and contrast, organize information, and find the main idea of a text. Graphic Organizer will provide benefits for two parties involved in the teaching and learning process, namely teacher and students. In fact, according to USAID (2014), the use of Graphic Organizer can improve students' academic achievement.

In learning advanced Indonesian, one of the lessons is to find the main idea of a paragraph. Erdiana (2017) states that a paragraph is the smallest unit of an essay that contains one main idea as the basis for developing an essay. Santika et al. (2019) states that the main idea of a paragraph tells the readers the thoughts of the author. The main idea of a paragraph is the core of the problem indicating by a general concluding statement about the content of the entire paragraph or ideas that contain general thoughts translated into several ideas supported by clear arguments (reasons). Based on this explanation, it can be concluded that the main idea of a paragraph is the main sentence that becomes the main point in an essay. In finding the main idea, the most important thing is to know how to distinguish the main sentence and the explanatory sentence (Prihatini, 2015).

\section{RESEARCH METHOD}

This study follows the Research and Development research. This type of research method creates a product (a model, module, or another method) and influences the product. Saputro (2017) states that Research and Development is the study of creating products that have been modified into new products. Thus, it can be concluded that Research and Development is a type of research method that focuses on an existing product that is re-modified into a new product with proven effectiveness and quality than the previous product. This research studies the use of audio-visual media based on a 
Graphic Organizer teaching Indonesian to the fifth-grade students at MIN 2 Labuhanbatu Selatan.

The researcher follows Sugiono's model as a reference. The model includes the potential and problems, collecting information, product design, design validation, design revision product testing, product revision, testing the product, revising the final product, and mass production. The stages above will produce an attractive and quality product that can be accepted by the wider community because it has carried out several tests on a product, such as validation, revision, and then testing the feasibility. The instruments used for this study include 1) preliminary instrument, 2) product development instrument, 3) product testing instrument (Prasetyo, 2012). The data were collected through interviews to collect suitable data and information to understand what actions can be taken to make audio-visual teaching media products based on Graphic Organizer.

The subject interviewed is a fifth-grade teacher at MIN 2 Labuhanbatu Selatan. Documentation was used to collect data about students who learn using audio-visual teaching media based on Graphic Organizer. The data were collected from a questionnaire given to experts, namely questionnaire for material experts, questionnaire or media experts, and also questionnaire for the students, and questionnaire for the teacher. The questionnaires were used to get answers about audio-visual media based on Graphic Organizer. The data were analyzed by using descriptive qualitative and quantitative (Saputro, 2017).

This study was conducted at MIN 2 Labuhanbatu Selatan, Kampung Rakyat District, Tanjung Medan Village, Labuhanbatu Regency. In this study, the object is the fifth-grade students of MIN 2 Labuhanbatu Selatan which consists of two classes totaling 65 students (29 male students and 36 female students). The researchers chose the class VB with a total of 32 students consisting of 12 male students and 20 female students to compare classes A and B in learning Bahasa Indonesia subject, especially in finding the main idea of a paragraph. Many students in class B did not complete the lesson. One of the lessons in Bahasa Indonesia subject is to find the main idea of a paragraph. The following data were obtained from grade VA and VB of MIN 2 Labuhanbatu Selatan, as shown in the following table: 
Table 2 The Fifth Grade students (Class V A and B) MIN 2 Labuhanbatu Selatan T.A $2020 / 2021$

\begin{tabular}{|c|c|c|c|}
\hline \multirow{2}{*}{ Class } & \multicolumn{2}{|c|}{ Number of students } & \multirow{2}{*}{ Total } \\
\cline { 2 - 3 } & Male & Female & \\
\hline V A & 17 & 16 & 33 \\
\hline V B & 12 & 20 & 32 \\
\hline
\end{tabular}

Development Research is only limited to the final stage of a product, namely audiovisual teaching media based on Graphic Organizer. Hidayat (2020) following Borg and Gall and was adapted by Sugiyono mentioned that the steps of the research procedures include; potential and problems, gathering information, product design, design validation, product revision, testing the product, revising the product, testing the product, revising the product and mass production. Based on the steps which have been stated, the researchers applied the nine steps of Sugiyono, including; potential and problems, gathering information, product design, design validation, design revision, product testing, product revision, testing the product, and final product revision.

\section{RESULTS}

This study creates audio-visual teaching media based on Graphic Organizer. The steps followed are:

\section{a. Potential Problems}

Interviews were conducted by researchers to find the potential problems that occurred in the fifth-grade students at MIN 2 Labuhanbatu Selatan, and it was found that the teaching media used was conventional teaching media such as the lecturing method and the achievement of grades obtained by students in Bahasa Indonesia subject. Some students were found to have not completed the KKM grades. In this case, there are no media that can be used to support the learning process, so the problem is the teacher's inaccuracy in applying an appropriate method and also the media provided to support the teaching process of Bahasa Indonesia which contains the lesson about finding the main idea in a paragraph.

b. Collecting information

After investigating the potential problems, the information that must be collected is to observe the teacher's handbook based on the material and design it into a lesson plan so that the product of audio-visual teaching media can be well structured. 


\section{c. The Product Design}

In the beginning, the researchers designed the product based on Lesson Plan that follows the Main Competence (KI) and the Basic Competence (KD) from the teacher's handbook that relates to the learning topic, namely Organ Gerak dan Manusia (Body Parts used for movement and Human). The information on the teacher's handbook became the design for the Lesson Plan.

d. The Product Validation

To get a good quality product, validation made by experts is needed. The assessment was carried out with two experts, namely material experts and media experts. Aspects validated by the material expert are such as (1) the quality of the content, namely the suitability of the material with $\mathrm{KI}$ and $\mathrm{KD}$, (2) the quality of the material, namely the images presented are appropriate to explain the human's and animal's body parts used for movement, to see whether the material has been explained correctly, how to find the main idea of a paragraph has been explained correctly, the material is presented in an orderly manner, and in general, this video has a quality that is suitable for the fifthgrade elementary students / MI students and (3) the language is straightforward and communicative as a learning media. The validator who is chosen as the material expert was Tri Indah Kusumawati, SS. M.Hum. The results of data obtained from the validation made by the material expert can be seen in the following table.

Table 3 The Validation Results of Material Expert

\begin{tabular}{|c|l|c|c|c|c|c|}
\hline NO & \multicolumn{1}{|c|}{ Indicator } & \multicolumn{5}{c|}{ Score } \\
\cline { 2 - 6 } & \multicolumn{1}{|c|}{$\mathbf{1}$} & $\mathbf{2}$ & $\mathbf{3}$ & $\mathbf{4}$ & $\mathbf{5}$ \\
\hline $\mathbf{1}$ & $\begin{array}{l}\text { The material is compatible with KI } \\
\text { and KD. }\end{array}$ & & & & $\sqrt{ }$ & \\
\hline 2 & $\begin{array}{l}\text { The images presented are } \\
\text { appropriate to explain the material } \\
\text { for human's and animal's body } \\
\text { parts used for movement. }\end{array}$ & & & & $\sqrt{ }$ & \\
\hline 3 & $\begin{array}{l}\text { Human's and animal's body parts } \\
\text { used for movement have been } \\
\text { explained correctly }\end{array}$ & & & & & \\
\hline
\end{tabular}




\begin{tabular}{|c|l|l|l|l|l|l|}
\hline 4 & $\begin{array}{l}\text { Strategies to find the main idea of a } \\
\text { paragraph has been explained } \\
\text { correctly }\end{array}$ & & & & $\sqrt{ }$ & \\
\hline 5 & $\begin{array}{l}\text { The material was presented in a } \\
\text { coherent and systematic manner }\end{array}$ & & & & $\sqrt{ }$ & \\
\hline 6 & $\begin{array}{l}\text { In general, the quality of the video } \\
\text { is suitable for the fifth-grade } \\
\text { elementary/ MI students. }\end{array}$ & & & & $\sqrt{ }$ & \\
\hline 7 & Straightforward & & & & $\sqrt{ }$ & \\
\hline 8 & Communicative & & & & $\sqrt{ }$ & \\
\hline
\end{tabular}

Validation made by media experts was carried out through a test. (1) The benefits and existing functions provide easiness when delivering the materials, the motivation given growing students' interest, and increasing students' creativity, (2) Visual media, such as choosing colors, backgrounds, texts, and animated images are visible, and the speed of changing slides is appropriate for students, the type of text can be easily read, and the size of the text is appropriate (3) the audio aspect, such as the rhythm of the voice presented by the narrator is suitable to the needs of students (not too slow and not too fast). The narrator's voice is heard clearly and informatively, the sound of the music fits the atmosphere and the image display, and the duration setting is appropriate (not too long and not too close) in the learning media. The validator for the media expert in this study is Dr. Nirwana Anas, M.Pd. The results of the validation for media experts can be seen in the following table.

Table 4 The Results of Validation Given by Media Experts

\begin{tabular}{|c|l|c|c|c|c|c|}
\hline NO & \multicolumn{1}{|c|}{ Indicator } & \multicolumn{5}{|c|}{ Score } \\
\cline { 3 - 7 } & & $\mathbf{1}$ & $\mathbf{2}$ & $\mathbf{3}$ & $\mathbf{4}$ & $\mathbf{5}$ \\
\hline 1 & $\begin{array}{l}\text { Clarifying and facilitating the delivery } \\
\text { of materials for students }\end{array}$ & & & $\sqrt{ }$ & & \\
\hline 2 & $\begin{array}{l}\text { Generating students' interest and } \\
\text { motivation }\end{array}$ & & & & $\checkmark$ & \\
\hline 3 & Improving students' creativity & & & $\sqrt{ }$ & & \\
\hline
\end{tabular}




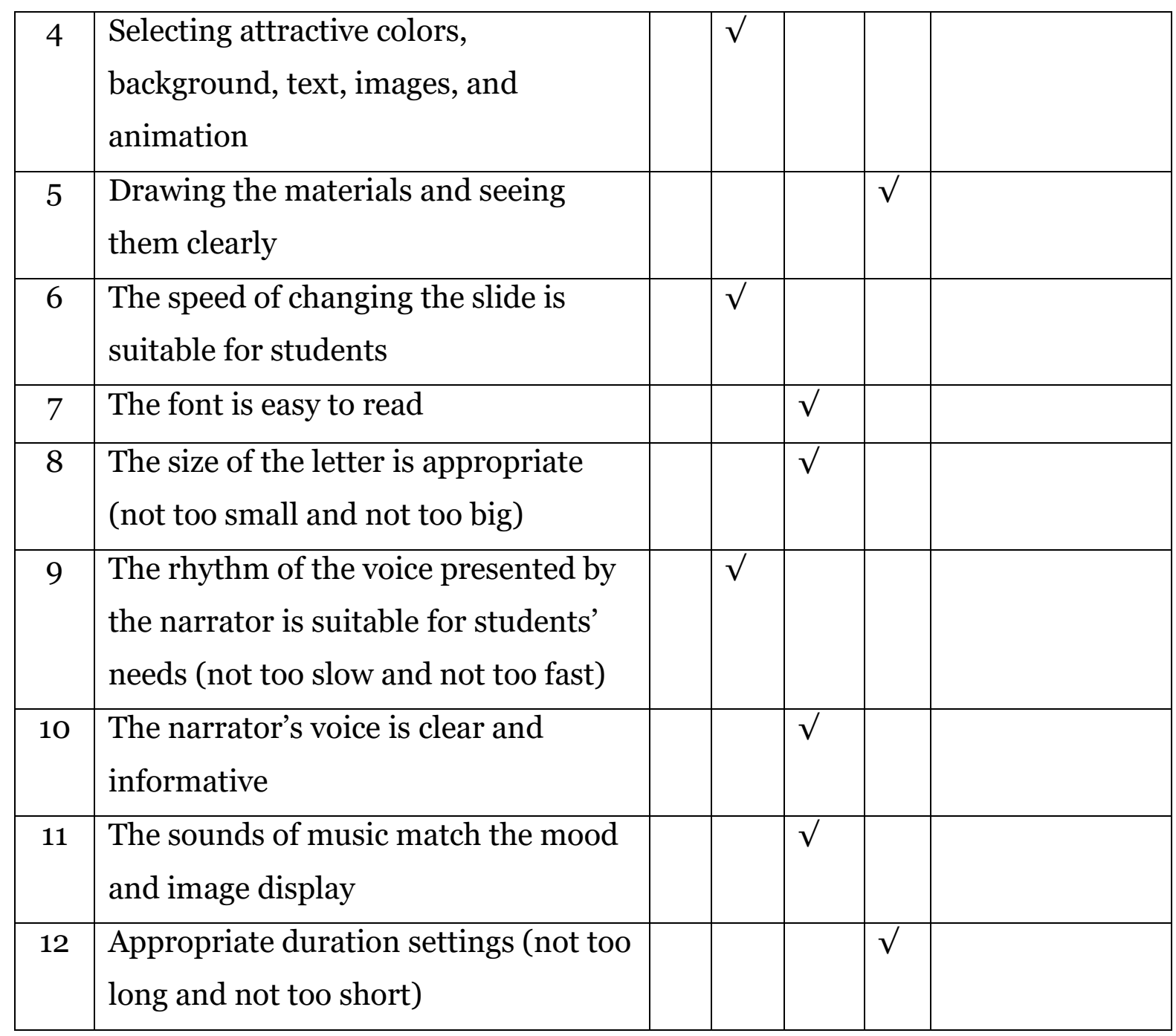

e. Revising the Design

From the material experts and media, the video produced by researchers can be described as follows. According to the instrument validation sheet by material experts, the researchers were given a final score of $80 \%$ which was in the range of 61 to 80 , so the "very good" level was obtained without revision. Meanwhile, according to the instrument validation sheet by media experts who were given the results, the researchers obtained the results to revise the display section regarding the use of graphic organizers.

f. Testing the Product

There are two ways to experiment on a product, namely; by testing the product on a small scale of students ( 8 students). The step taken by the students was to fill out the questionnaire that had been distributed. The small-scale field experiment was conducted by obtaining data from students' responses. In the large-scale testing, the student's job was to fill out the questionnaire prepared for 24 students, including a 
questionnaire for a teacher. The data of the field experiment large-scale of participants were obtained from teacher's and students' responses. The experiment was conducted on the fifth-grade students of MIN 2 Labuhanbatu Selatan.

g. Revising the Final Product

When the product was revised and tested by the students, many of them thought the product was suitable for learning. It was easier for them to understand the materials by using the product. Therefore, this study is similar to the relevant studies in that it was found successful to improve students' interest in learning the subject.

\section{The Product Validity}

Material experts give a score on each criterion based on aspects of content quality, material quality, and language with a percentage of $80 \%$. This validity is considered in the very good category according to the criteria of the product validity table. Therefore, there is no revision of the material. Meanwhile, the validity of the media experts received a score of $60 \%$, and this was considered quite valid, so it needs some revisions. Therefore, it is necessary to revise the audio-visual teaching media based on the graphic organizer. After the revision, the graphic organizer was validated again by media experts, and the score obtained was $86.6 \%$, and which was considered in the very good category. The information without revision was by the criteria for the product validity table.

\section{The Product Practicality}

The practicality of the product was obtained based on interviews and questionnaires. The final score of students in the small-scale experiment is $97.6 \%$, and this is considered in the very good category, and it is seen from the practicality criteria. The data obtained from the students' responses can be seen in the following table: 
Table 5 Results of Responses Received from Small-Scale Students

\begin{tabular}{|c|c|c|c|}
\hline NO & Aspect & $\begin{array}{c}\text { Score } \\
(\%)\end{array}$ & $\begin{array}{l}\text { Practicality } \\
\quad \text { Level }\end{array}$ \\
\hline 1 & $\begin{array}{l}\text { Do you feel happy when learning through } \\
\text { videos? }\end{array}$ & $100 \%$ & Very Good \\
\hline 2 & $\begin{array}{l}\text { Are you interested in learning about the main } \\
\text { idea of a paragraph about the human's and } \\
\text { animal's body parts using instructional video? }\end{array}$ & $100 \%$ & Very Good \\
\hline 3 & $\begin{array}{l}\text { Do you want to know and understand more } \\
\text { about finding the main idea of a paragraph? }\end{array}$ & $100 \%$ & Very Good \\
\hline 4 & $\begin{array}{l}\text { Is learning to find the main idea of a paragraph } \\
\text { interesting for you? }\end{array}$ & $100 \%$ & Very Good \\
\hline 5 & $\begin{array}{l}\text { Is the presentation of human and animal body } \\
\text { parts used for movement clear in the video? }\end{array}$ & $88 \%$ & Very Good \\
\hline 6 & $\begin{array}{l}\text { Is the quality of the images displayed on the } \\
\text { video good? }\end{array}$ & $100 \%$ & Very Good \\
\hline 7 & Is the quality of the text used in the video good? & $100 \%$ & Very Good \\
\hline 8 & $\begin{array}{l}\text { Do you understand how to find the main idea of } \\
\text { a paragraph through videos? }\end{array}$ & $100 \%$ & Very Good \\
\hline 9 & $\begin{array}{l}\text { Is your curiosity in learning through videos } \\
\text { high? }\end{array}$ & $88 \%$ & Very Good \\
\hline 10 & $\begin{array}{l}\text { Is the clarity of images and texts on the material } \\
\text { appropriate? }\end{array}$ & $100 \%$ & Very Good \\
\hline & Total & $97,6 \%$ & Very Good \\
\hline
\end{tabular}

Then the final score given by the students in the large-scale test is $98.4 \%$, and it is considered in the very good category. The data obtained from students' responses can be seen in the following table: 
Euis Indah Kesuma Ningsih et al./ JURNAL TARBIYAH 28 (2) (2021) 65-81

Table 6 The Results of Responses Given by Large-Scale Students

\begin{tabular}{|c|l|c|c|}
\hline NO & \multicolumn{1}{|c|}{ Aspect } & $\begin{array}{c}\text { Score } \\
\text { (\%) }\end{array}$ & $\begin{array}{l}\text { Practicality } \\
\text { Level }\end{array}$ \\
\hline 1 & Do you feel happy when learning using videos? & $100 \%$ & Very Good \\
\hline 2 & $\begin{array}{l}\text { Are you interested in learning about finding the } \\
\text { main idea of a paragraph about the body parts of } \\
\text { humans and animals using instructional video? }\end{array}$ & $100 \%$ & Very Good \\
\hline 3 & $\begin{array}{l}\text { Do you want to know and understand more about } \\
\text { finding the main idea of a paragraph? }\end{array}$ & $100 \%$ & Very Good \\
\hline 4 & $\begin{array}{l}\text { Is learning to find the main idea of a paragraph } \\
\text { through vide is interesting? }\end{array}$ & $100 \%$ & Very Good \\
\hline 5 & $\begin{array}{l}\text { Is the presentation of human and animal body } \\
\text { parts in the video clear? }\end{array}$ & $92 \%$ & Very Good \\
\hline 6 & $\begin{array}{l}\text { Is the quality of the image displayed on the video } \\
\text { good? }\end{array}$ & $96 \%$ & Very Good \\
\hline 7 & $\begin{array}{l}\text { Is the quality of the text displayed on the video } \\
\text { good? }\end{array}$ & $100 \%$ & Very Good \\
\hline 8 & $\begin{array}{l}\text { Do you understand how to find the main idea of a } \\
\text { paragraph by using video? }\end{array}$ & $100 \%$ & Very Good \\
\hline 9 & Is your curiosity in learning through videos high? & $96 \%$ & Very Good \\
\hline 10 & $\begin{array}{l}\text { Is the clarity of images and texts on the material } \\
\text { appropriate? }\end{array}$ & $100 \%$ & Very Good \\
\hline & \multicolumn{1}{|c|}{ Total } & $98,4 \%$ & Very Good \\
\hline
\end{tabular}

The final score received from the questionnaires answered by the teacher is $100 \%$ and it is included in the very good category. The following table shows the data obtained:

Table 1.7 The Results of Questionnaires Answered by a Teacher

\begin{tabular}{|c|l|c|c|}
\hline NO & \multicolumn{1}{|c|}{ Aspect } & $\begin{array}{c}\text { Score } \\
\text { (\%) }\end{array}$ & $\begin{array}{l}\text { Practical } \\
\text { ity Level }\end{array}$ \\
\hline 1 & $\begin{array}{l}\text { Do you enjoy using audio-visual media based on the } \\
\text { graphic organizer in teaching? }\end{array}$ & $100 \%$ & Very good \\
\hline
\end{tabular}




\begin{tabular}{|c|l|c|c|}
\hline 2 & $\begin{array}{l}\text { Are you interested in teaching human's and animals' } \\
\text { body parts to find the main idea of a paragraph by } \\
\text { using audio-visual media based on a graphic } \\
\text { organizer? }\end{array}$ & $100 \%$ & Very good \\
\hline 3 & $\begin{array}{l}\text { Do you think that the learning material for human's } \\
\text { and animal's body parts is interesting to help students } \\
\text { find the main idea of a paragraph using audio-visual } \\
\text { teaching media based on the graphic organizer? }\end{array}$ & $100 \%$ & Very good \\
\hline 4 & $\begin{array}{l}\text { Do audio-visual teaching media based on graphic } \\
\text { organizers help you teach learning materials? }\end{array}$ & $100 \%$ & Very good \\
\hline 5 & $\begin{array}{l}\text { Is the presentation of human's and animal's body parts } \\
\text { clear by using the audio-visual teaching media based } \\
\text { on the graphic organizer? }\end{array}$ & $100 \%$ & Very good \\
\hline 6 & $\begin{array}{l}\text { Is the quality of the images displayed on the audio- } \\
\text { visual teaching media based on the graphic organizer } \\
\text { good? }\end{array}$ & $100 \%$ & Very good \\
\hline 7 & $\begin{array}{l}\text { Is the quality of text displayed on the audio-visual } \\
\text { teaching media based on graphic organizers good? }\end{array}$ & $100 \%$ & Very good \\
\hline 8 & Are the images and texts very clear? & $100 \%$ & Very good \\
\hline & \multicolumn{2}{|c|}{ Total } & Very good \\
\hline
\end{tabular}

The reviews on the product were also obtained based on interviews conducted with the teacher who used the audio-visual teaching media based on Graphic Organizer. Based on the results of the interviews, it can be concluded that the use of audio-visual teaching media based on Graphic Organizer is effective to improve students' ability to find the main idea of a paragraph, so the students can become more motivated in their learning process.

\section{The Product Effectiveness}

The effectiveness of the product is based on the results of field experiments through pre-test and post-test given to students to see their score before and after using the audio-visual media based on Graphic Organizer. In this test, a sample of 32 people was used, namely the fifth-grade students at MIN 2 Labuhanbatu Selatan. This field experiment aims to test the effectiveness of the product that has been created. The pre- 
test was used to answer the ability instrument given. After the test was carried out, the learning activities were conducted by using audio-visual teaching media based on Graphic Organizer led by the teacher, and the score obtained was 94.11. After using the audiovisual teaching media based on Graphic Organizer, the post-test was given to the students. The average score of the pre-test before using the audio-visual teaching media based on Graphic Organizer was 76.87 while the average score that students got after using the audio-visual teaching media based on Graphic Organizer was 94.37. There is a difference of 17.5. Therefore, it can be concluded that the product is effective in improving students' ability to find the main idea of a paragraph. To see students' improvement in the learning process using the audio-visual teaching media, the total score was summed and distributed to all criteria, and the final score obtained was 84 .

\section{CONCLUSION}

After following the procedures of making development media, testing audio-visual teaching media based on Graphic Organizer to find the main idea of a paragraph, it can be concluded as follows. The validation of material experts was found to be $80 \%$ in the good category, the validation of media experts was found to be $60 \%$ in the sufficient category, and the validation of media experts was revised and received a score of $86.6 \%$ in the good category. The responses given by students on a small scale indicate a score of $97.6 \%$ in the very good category, and the responses given by students on a large scale indicate a score of $98.4 \%$ in the very good category. Meanwhile, the responses given by the teacher are $100 \%$ in the very practical category. The product was tested before it was used, and it received a score of 76.87. Meanwhile, the average score after using the audiovisual teaching media based on Graphic Organizer is 94.37 which indicates that there is an increase of 17.5 in students' scores. In addition, for the improvement of students' learning in using the product, it was found to be 84 , and the result for teacher's observation in using the product was found to be 94.44 . Therefore, it can be understood that the score before and after using the product is different. 


\section{REFERENCES}

Anggriani, dkk, 2020. Pengembangan Bahan Ajar Membaca Sastra Berbasis Graphic Organizer Venn Diagram di Sekolah Dasar. Jurnal Basicedu Vol. 4 No 4

Ani, Ayang, 2019. Penerapan Metode Graphic Organizer Pada Pembelajaran Bahasa Indonesia Siswa Kelas V Sd Negeri o6 Bathin Solapan. Jurnal Pajar Vol 3 No 3

Candler, Laura. 2012. Graphic Organizers for Reading. Teaching Resources. Inc.

Damanik, R., Sagala, R. W., \& Rezeki, T. I. (2021). Keterampilan Dasar Mengajar Guru (Vol. 1). umsu press.

Erdiana, 2017. Pengaruh Keefektifan Membaca Cepat Terhadap Kemampuan Menemukan Ide Pokok Paragraf” Jurnal Diksatrasia. Vol. 1 No 2

Gurusinga Mayasari Laura, 2016. Hubungan Keterampilan Membaca Intensif Dengan Kemampuan Menemukan Ide Pokok Paragraf Siswa Kelas Viii Smp Pencawan Medan Tahun Pelajaran 2012-2013. Jurnal Edukasi Kultura. Vol 3 No 1

Hammid, dkk 2020. Media Pembelajaran. Medan: Yayasan Kita Mneulis

Hidayat dkk, 2020. Pengembangan Model Pembelajaran Atletik Nomor Lari Berbasis Permainan Pada Siswa Sekolah Dasar, Jawa Tengah: CV. Sarnu Untung

Muhammad, 2010. Tafsir Ibnu Katsir Jilid 1. Pustaka Imam Syafi’i

Mulyani, Asep, 2014. Grafic Orgaizer dalam Pembelajaran. Jurnal Scientiae Education. Vol. 3 No 2

Prasetyo, I, 2012 . Teknik Analisis Data Dalam Research And Development. UNY: Fakultas Ilmu Pendidikan

Prihantini, Ainia. 2015. Master Bahasa Indonesia, Yogyakarta: Penerbit B firs. 
Purwono, Joni, dkk, 2014. Penggunaan Media Audio-Visual Pada Mata Pelajaran Ilmu Pengetahuan Alam Di Sekolah Menengah Pertama Negeri 1 Pacitan. Jurnal Teknologi Pendidikan dan Pembelajaran. Vol. 2 No 2

Santika, dkk, 2019. Pengaruh Model Pembelajaran Cooperative Integrated Reading And Composition (Circ) Terhadap Kemampuan Menentukan Ide Pokok Paragraf Siswa Kelas VSd Negeri oo3 Pulau Kopung Kecamatan Sentajo Raya Kabupaten Kuantan Singingi. Jurnal Pajar. Vol 3 No 2

Saputro, Budiyono, 2017. Manajemen Penelitian Pengembangan ( Research \& Development ), Yogyakarta: Aswaja Perssindo

Sudarmawan, dkk, 2014. The Effect Of Graphic Organizers And Text Types On The Student Reading Competency at SMAN 8 Denpasar. Jurnal Program Pascasarjana Universitas Pendidikan Ganesha. Vol. 2 No 1

Trisna, febri, 2017. Pengaruh Metode Pembelajaran Guided Note Taking Dengan Berbantuan Media Audio Visual Terhadap Minat Dan Hasil Belajar Siswa Kelas V Pada Mata Pelajaran IPA Di SD Markus Medan. Jurnal Prosiding Seminar Nasional III Biologi dan Pembelajarannya ISBN : 978-602-5097-61-4

Ummysalam, 2017. Buku ajar Kurikulum bahan ajar dan media pembelajaran PLS. Yogyakarta: Penerbit Deepublish

USAID. 2014. Pebelajaran Literasi Kelas Awal di LPTK. Jakarta: USAID PRIORITAS 